\title{
MULTIMODALITY IN TEACHING ACADEMIC RESEARCH SKILLS: THE COGNITIVE METHODOLOGY CASE OF CRITICAL ASSESSMENT COMPETENCE SHAPING
}

\author{
Irina Ubozhenko ${ }^{1}$, Zihao Zhang ${ }^{2}$ \\ ${ }^{1}$ Department for Foreign Languages, National Research University Higher School of Economics, Russia \\ ${ }^{2}$ School of International Affairs, Faculty of World Economy and International Affairs, \\ National Research University Higher School of Economics, Russia \\ E-Mail: ${ }^{1}$ iubojenko@hse.ru, ${ }^{2}$ zhangzihao0710@gmail.com
}

\begin{abstract}
In the proposed case study the authors show, how the original methodological algorithm may be used to creatively teach basic academic research skills and shape the fundamental research competence of professional literature critical assessment. The didactic technique of key concepts mind-mapping and presenting critical thinking reports by means of cognitive comprehensive reading professional academic literature is going to be demonstrated in the current paper as a creative tool of training analytical skills of critical evaluation, necessary for post graduate students involved in their early research activities.
\end{abstract}

Key words: teaching research skills, academic writing, multimodality in teaching methodology, cognitive creative teaching techniques

"Cognitive information presents the world to the human mind as sensual and intellectual images of facts, events, objects, etc., while language presents both the world and knowledge about it as assemblages of language symbols."

(Chernyakhovskaya 2011)

\section{INTRODUCTION}

The major didactic task in higher school education in Russia now is to assist post graduate students of national research universities in their joining the international academic community by not only improving their level of foreign languages knowledge but also by mastering critical academic writing and speaking skills in order to help them share their ideas both in recognized professional research journals and at expert panels not only with young scholars of similar academic rank but also with experienced professors, including the presentation of their research findings at scientific conferences and any other kinds of international events in the academic world. 
One of the most often difficulties faced and to be overcome by young researchers, both Russian and foreign ones, is the methodical demand for multimodality in creating oral (a speech), graphic (a scheme or a presentation), as well as written types (a research proposal, a book review, a paper) of academic discourses. And it is the teacher (tutor, academic adviser, academic language style consultant), who should be willing and proficient to help them in acquiring those skills: namely, the skills of cognitive reading and comprehending, combined with critical thinking analysis and expert evaluation of relevant academic literature, including making presentations and writing abstracts and research papers of different formats (articles, critical notes and reports, theoretic and conceptual contemplation essays, etc.).

\section{CASE Study Methodology}

The case presented in the paper is related to the new academic course approved by the Research Council of the Political Science Post Graduate Research Academic School of National Research University Higher School of Economics (Moscow) that was elaborated and introduced by the author of the paper to the $\mathrm{PhD}$ students and entitled "Modern Research Paradigms through Literature Reviews". According to the program, the course meets the minimum requirements of the knowledge and skills of a $\mathrm{PhD}$ student, and determines the content and types of classes, as well as course assessment criteria. The program in its turn is designed for teachers of this discipline, learning assistants and students of political science $\mathrm{PhD}$ programs.

The major objectives of the course involve the following:

- enriching the knowledge and development of experience in the implementation of scientific and expert-analytical professional activities in terms of the urgent demand to integrate into global information networks and master technologies in the field of political science;

- studying the patterns of structuring linguistic-cultural features of valid scientific and research sources (including popular science discourse type) in English;

- improving the language skills of speaking, listening, reading, participating in public scholarly debate and writing academic texts;

- training academic skills of working with scientific information sources, critical, cognitive reading, peer reviewing, correct referencing and reviewing scientific texts;

- using computer and information technologies (ICT) in the process of academic reading, interpretation, presentation of texts submitted for discussion and writing reviews of English-language academic sources on the major specialty.

The course is mandatory and delivered to the second-year PhD students as a part of their professional development. The course consists of two modules: a lecture course on new paradigms in academic literature and project work seminars (See Table 1 below). 
Table 1 Course Syllabus and Class Formats

\begin{tabular}{|c|c|}
\hline Theme & Class Format \\
\hline $\begin{array}{l}\text { Lecture 1. } \\
\text { Introduction to Cognitive, Neuro, } \\
\text { Discourse Analysis Approaches to } \\
\text { Political Studies }\end{array}$ & An interactive cognitive reading lecture \\
\hline $\begin{array}{l}\text { Lecture } 2 . \\
\text { Cognitive and Neuro Paradigms: } \\
\text { Interdisciplinary Approaches to Political } \\
\text { Studies }\end{array}$ & An interactive cognitive reading lecture \\
\hline $\begin{array}{l}\text { Lecture } 3 . \\
\text { Cognitive Discourse Analysis as an } \\
\text { Interdisciplinary Approach to Political } \\
\text { Studies. Part I. Cognitive Linguistics }\end{array}$ & An interactive cognitive reading lecture \\
\hline $\begin{array}{l}\text { Lecture } 4 . \\
\text { Cognitive Discourse Analysis as an } \\
\text { Interdisciplinary Approach to Political } \\
\text { Studies. Part II. Discourse Analysis and } \\
\text { Political Cognition }\end{array}$ & An interactive cognitive reading lecture \\
\hline $\begin{array}{l}\text { Lecture } 5 . \\
\text { An Interdisciplinary Approach to Political } \\
\text { Studies: Introduction to a Bio Paradigm }\end{array}$ & An interactive cognitive reading lecture \\
\hline $\begin{array}{l}\text { Lecture } 6 . \\
\text { Integrative Research Methodology: } \\
\text { Interdisciplinary, Multidisciplinary, } \\
\text { Transdisciplinary Approaches }\end{array}$ & An interactive cognitive reading lecture \\
\hline $\begin{array}{l}\text { Lecture } 7 . \\
\text { Revision of the Discussion Issues Raised } \\
\text { in the Lecture Course }\end{array}$ & An interactive colloquium \\
\hline $\begin{array}{l}\text { An interactive project seminar. } \\
\text { Project Team working / making a } \\
\text { collaborative presentation }\end{array}$ & $\begin{array}{l}\text { An expert panel role play: } \\
\text { Making a collective presentation with several } \\
\text { people speaking } \\
\text { (several selected papers relevant to the subject } \\
\text { may be discussed) }\end{array}$ \\
\hline $\begin{array}{l}\text { An individually prepared book review is } \\
\text { presented as a report with its further Q-A } \\
\text { discussion in class }\end{array}$ & A mock conference \\
\hline
\end{tabular}

Consequently, our research is presented as a case description paper and makes an attempt to introduce and discuss the teaching methodological technique tool kit of combining writing and speaking skills development in a single consecutive cognitive algorithm learning system. The research relies on the cross-disciplinary method of theoretical observation, rational analysis and critical evaluation, and may be split into four logically intertwined parts that correlate with the four-step teaching algorithm supported by a consecutive set of illustrative patterns. 


\section{BACKGROUND AND PROBLEM STATEMENT}

The class model and the didactic algorithm presented in the paper may rely on the sources that primarily center round three major problem issues: 1) what are the basic research skills demanded from beginner researchers and needed nowadays (Polziehn 2011) (see also, for instance, the current guide to the research staff of the University of Edinburg or the Code of Good Practice in Research of the University of Glasgow ${ }^{1}$ ), 2) the ways of applying multimodality to teaching as a form of creative cognitive didactic instruments (Jian-xin 2014, Husarova 2012), and 3) the development of critical thinking and assessment competence through creative cognitive interaction in learning (Marchetti, Cullen 2016; Paul, Elder 2007).

Stressing the core ideas accumulated in previous research experience, we assume it significant to emphasize the so-called "learner-as-creator" paradigm as having obvious merits and effectively transforming today the learning space into a creative project environment.

As for efficient instrumental techniques used in teaching a foreign language, Schultz (1991, p.981) was among the first to claim the interrelation between mapping and cognitive development, particularly in writing: “... the language base necessary for the expression of analytical thought (particularly as manifested through writing) is different from the one needed to produce experiential or quotidian forms of practical expression. The language that analytical thinking requires involves a sophisticated use of grammar and vocabulary, as well as organizational and logical thinking skills. By contrast, the argumentative essay depends on more complex higher level cognitive processes. In producing an argumentative paper, writers first think of a core concept and from there generate any number of related (and sometimes unrelated) ideas, any and all of which might cause them to revise and even lose the initial central idea as they reflect upon implications and test the validity of their hypotheses. Thus in the process of drafting the preliminary version of an essay writers commonly create what Flower calls a multidimensional network of ideas".

Years later Matsumura, Correnti, and Wang (2015) wrote about classroom writing tasks and the specifics of students' analytic text-based writing, stressed the importance of cognition to students' academic writing, and proved that students necessarily needed to be provided with writing tasks that supported the high-level thinking about what they were reading.

Thus the problem statement of our case study may be formulated as follows: supposing, multimodality is a productive tool of teaching academic research skills, certain cognitive elements of the didactic methodology may facilitate the process of students' critical assessment competence shaping.

\footnotetext{
${ }^{1}$ https://www.gla.ac.uk/media/media_614208_en.pdf
} 


\section{RESEARCH DESIGN}

\subsection{Step 1: Interactive Lectures with the Elements of Cognitive Reading}

Here we suggest the reader an example of a logical segment of a class presentation accompanying an interactive lecture of a teacher, with the elements of key words level mind-mapping teaching technique and debate triggering discussion points (Fig. 1).
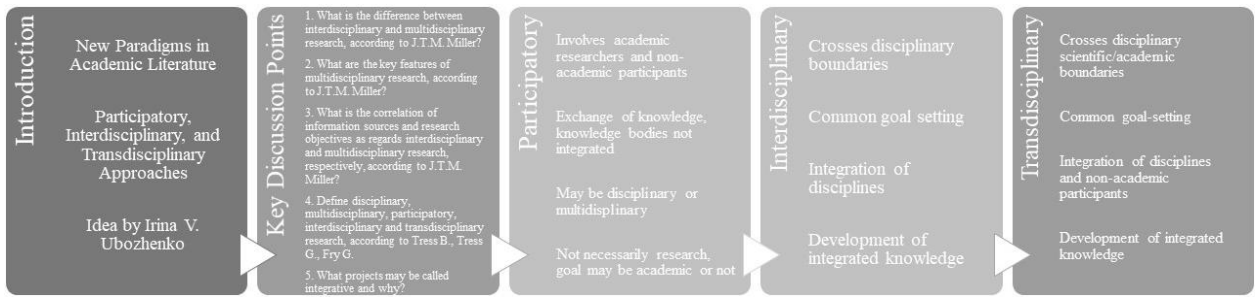

Fig. 1 Interactive Lectures with the Elements of Cognitive Reading

\subsection{Step 2: Key Literature Sources Mind Mapping Presentation}

This is an example of a mind mapping scheme of topical literature sources selection illustrated by a student and then presented in class (Fig. 2).

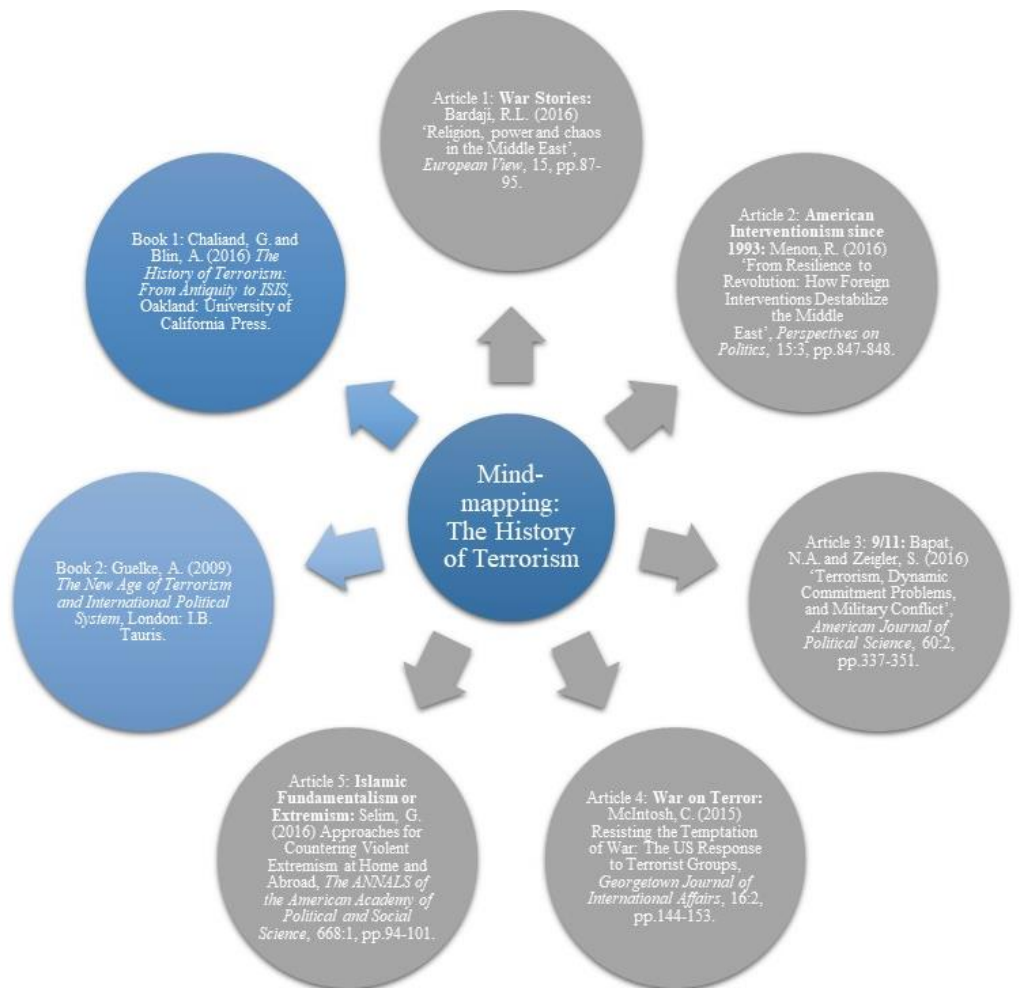

Fig. 2 Key Literature Sources Mind Mapping Presentation 


\subsection{Step 3: Presentation Making Followed by a Panel Discussion in Class}

We give an example of core presentation slides demonstrated by a student, while speaking in class and reporting on the popular science book referred to their thesis subject, cognitively read by them, critically analyzed and finally selected for writing a review (or often asked to be reviewed by the editor of an appropriate journal). Again the elements of key words ranking mind-mapping might be found here, but elaborated this time independently by a student, not a teacher (Fig. 3).

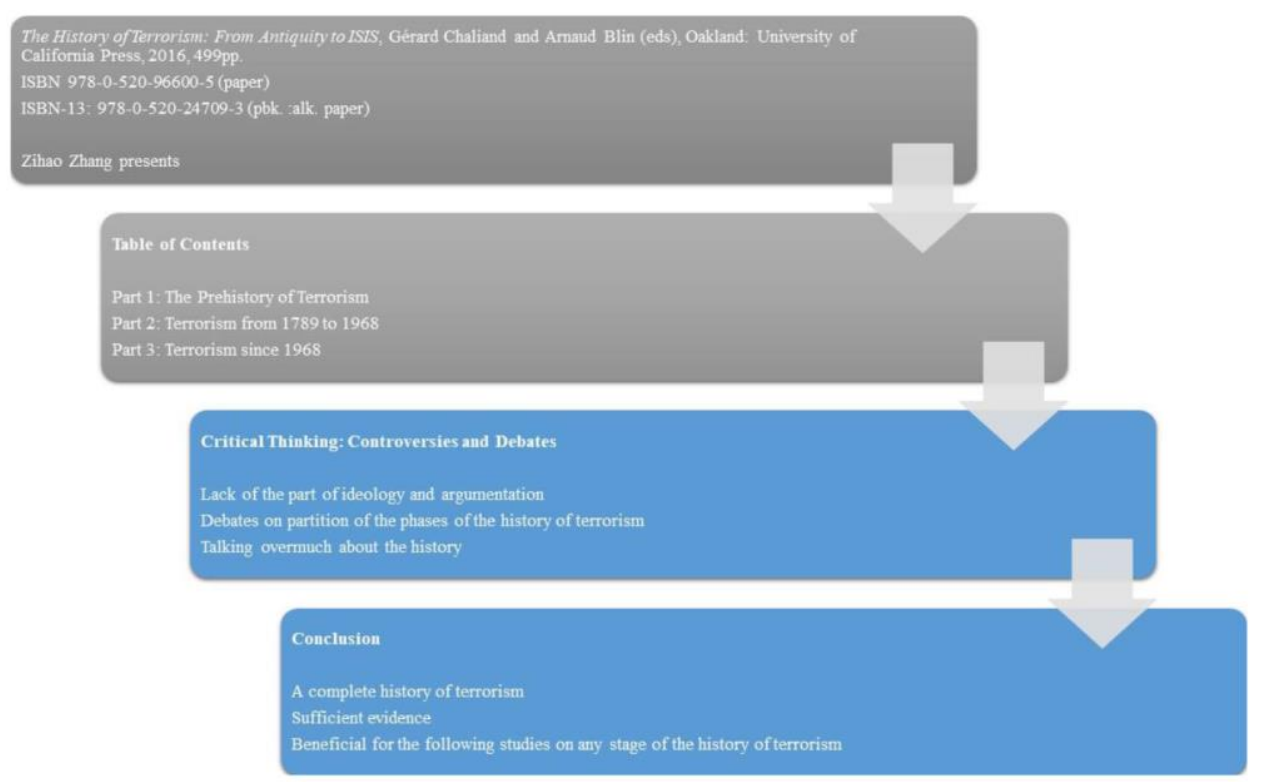

Fig. 3 Presentation Making Followed by a Panel Discussion in Class

\subsection{Step 4: Writing a Book Review (Sample of a Publication Project)}

As it was mentioned above, according to the guide to doctoral researchers of the University of Edinburgh ${ }^{2}$, the key research skills cover the abilities to collect, collate, critically analyze, synthesize, summarize, report and disseminate information, which, in turn, include searching literature techniques and writing effective literature reviews. Below you can see the complete result, ready to be submitted for publication, of the didactic mechanism illustrated in our paper. (In the left column we show the approximate assisting structure prompt, similar to the most of the journals' guides for book reviewers, suggested to the students by a teacher in advance. We give here (Table 2) the full text of a book review as it might help the reader trace the correlation of the teacher's assistance phrases on the left with the $\mathrm{PhD}$ student's written result on the right).

\footnotetext{
${ }^{2}$ http://www.docs.hss.ed.ac.uk/iad/Postgraduate/PhD_researchers/PhD_Skills_Guide.doc
} 
Table 2 History of Terrorism: From Antiquity to ISIS

\begin{tabular}{|c|c|}
\hline Bibliographic information & $\begin{array}{l}\text { Gérard Chaliand and Arnaud Blin (eds), Oakland: } \\
\text { University of California Press, 2016, 499pp. } \\
\text { ISBN 978-0-520-96600-5 (paper) } \\
\text { ISBN-13: 978-0-520-24709-3 (pbk. :alk. paper) }\end{array}$ \\
\hline Introduction & $\begin{array}{l}\text { The History of Terrorism: From Antiquity to ISIS is } \\
\text { a monograph that describes the long history of } \\
\text { terrorism, from the genesis of terrorism to the } \\
\text { contemporary shape of terrorism. It is less of a }\end{array}$ \\
\hline Statement of book's purpose & $\begin{array}{l}\text { textbook of history or political science, more of a } \\
\text { refined statement that allows more people truly to } \\
\text { know, what terrorism is and then seriously to think, }\end{array}$ \\
\hline Statement about the editors and authors & $\begin{array}{l}\text { how to eliminate terrorism. The authors of this } \\
\text { book, Gérard Chaliand and Arnaud Blin, are experts } \\
\text { in political science and meanwhile in other research } \\
\text { fields, such as geography and history. They have a } \\
\text { number of respective professional works and } \\
\text { collaborative works in French and English, and } \\
\text { some of these publications have been translated into } \\
\text { other languages. }\end{array}$ \\
\hline Placing the book in a context & $\begin{array}{l}\text { The original intention to write the book is due to the } \\
\text { event of September } 11 \text { in } 2001 \text {. They believe, that it } \\
\text { is time to remind the public of it and to realize, how } \\
\text { necessary countering terrorism is and how bad the }\end{array}$ \\
\hline $\begin{array}{l}\text { Statement about book's genre and } \\
\text { potential significance }\end{array}$ & $\begin{array}{l}\text { aftermaths terrorism brings us are. Having been first } \\
\text { published in French in 2004, the English edition of } \\
\text { this book was published by the University of } \\
\text { California Press in } 2007 \text {. In light of new terrorist } \\
\text { incidents and the changes of the nature of terrorism } \\
\text { emerging, Chaliand and Blin's book, by now, has } \\
\text { been edited few times. The latest edition of this } \\
\text { book, published in 2016, added a new preface and a } \\
\text { new chapter. The former explains the reason why } \\
\text { they decided to make changes and eventually } \\
\text { publish an updated edition; the latter focuses on the } \\
\text { rise of the new terrorist group after al-Qaeda, } \\
\text { considering that the Islamic State (IS) as the latest } \\
\text { concrete shape of terrorism has formed. Therefore, } \\
\text { the latest title sounds as "The History of Terrorism: } \\
\text { From Antiquity to ISIS" instead of the previous one } \\
\text { "The History of Terrorism: From Antiquity to al } \\
\text { Qaeda". }\end{array}$ \\
\hline Overall evaluation & $\begin{array}{l}\text { This notable research work is both practical for the } \\
\text { popularization of science and theoretical for } \\
\text { academic research. It introduces different stages of } \\
\text { the rise of terrorism with subjective opinions of two } \\
\text { authors, although the contents in the main body may } \\
\text { look obviously as narrative and descriptive. The } \\
\text { analysis and argumentation on the rise of terrorism } \\
\text { in the book are made with preciseness, based on } \\
\text { certain evidence. }\end{array}$ \\
\hline
\end{tabular}




\begin{tabular}{|c|c|}
\hline Summary of the book's beginning & $\begin{array}{l}\text { The book begins with the genesis of terrorism } \\
\text { from the ancient era. It describes the form of } \\
\text { assassination, or political assassination, as the } \\
\text { earliest shape of terrorism in antiquity. It claims } \\
\text { the so-called first terror attack was made by } \\
\text { Zealots in Palestine, and thus the Zealot sect } \\
\text { could be seen as one of the earliest terrorist } \\
\text { groups, although it could not be ensured if it was } \\
\text { the first terrorist organization in history. This } \\
\text { viewpoint is supported by two main ancient } \\
\text { references composed by Flavius Josephus, which } \\
\text { was named Jewish Antiquities and published } \\
\text { around in 93-94 C.E., and around in, and which } \\
\text { relates to the Jewish War and was published } \\
\text { between 75-79 C.E., according to Chaliand and } \\
\text { Blin. However, in terms of ideology, it is still } \\
\text { difficult to make sure, when the concept } \\
\text { formation of terrorism was completed in the } \\
\text { human mind. The first part, at the same time, } \\
\text { proposes the difference between political } \\
\text { assassination and terrorist crime and claims that } \\
\text { terrorist crimes include not only assassination } \\
\text { with political ambitions or religious aims but also } \\
\text { other violent forms of terror. It points out there is, } \\
\text { perhaps, no persuasive theory able to confirm } \\
\text { merely radical or extreme political violence; as } \\
\text { tyrannicide could not be thought as a typical } \\
\text { terrorist crime, because it is evitable to have the } \\
\text { subjective point of view or subjectivity while } \\
\text { defining despotism. In order to argue this } \\
\text { viewpoint, the second chapter of this part refers } \\
\text { to the discourse of French media characterizing } \\
\text { both Saddam Hussein and George W. Bush } \\
\text { during the invasion of Iraq in } 2003 \text {. }\end{array}$ \\
\hline More summary of later parts of the book & $\begin{array}{l}\text { The second part concentrates on the status of } \\
\text { terrorism in modern history. 1789, in Chaliand } \\
\text { and Blin's view, is regarded as the beginning of } \\
\text { modern terrorism, and it was exactly the time, } \\
\text { when the French Revolution broke out. } \\
\text { Compared with previous forms of violence tied to } \\
\text { political figures, the French revolutionary terror } \\
\text { was a real etymon of the term "terrorism" and } \\
\text { contributed to "prevalence" of terrorism in a } \\
\text { couple of oncoming years, claim Chaliand and } \\
\text { Blin. Meanwhile, "state terrorism" as a } \\
\text { subcategory of terrorism was also created during } \\
\text { the period of the French Revolution. } \\
\text { Furthermore, terrorism experienced its "golden } \\
\text { age" in the late } 19 \text { th and early 20th centuries. } \\
\text { During this period terrorism largely expanded } \\
\text { and broke through the limit of borders, triggering }\end{array}$ \\
\hline
\end{tabular}




\begin{tabular}{|c|c|}
\hline & $\begin{array}{l}\text { a movement toward global domain, with the early } \\
\text { stage of globalization forming. } \\
\text { The third part pays attention to the contemporary } \\
\text { pattern of a terrorist crime. This part selects } 1968 \\
\text { as the turning point and the time of the rise of } \\
\text { contemporary terrorism. A large number of } \\
\text { similar terrorist activities simultaneously } \\
\text { emerged in different continents and countries, } \\
\text { and mainly in the Middle East, and terrorism } \\
\text { grew up sharply from } 1968 \text { to } 1979 \text {, and to } 1983 \text {. } \\
\text { The destructiveness and impact of terrorism were } \\
\text { much more influential than before. Chaliand and } \\
\text { Blin illustrate that terrorist groups, such as the } \\
\text { radical Sunni Islamists of Hamas and al-Qaeda, } \\
\text { were abnormally active during this period. One } \\
\text { of these terrorist organizations led to the event of } \\
\text { 9/11, and some others triggered further terror } \\
\text { attacks. Then, the emergence of the IS made } \\
\text { "religious terrorism" more extreme and jihadism } \\
\text { escalated. The IS can be regarded as a set of } \\
\text { "religious terrorism" and "global terrorism" that } \\
\text { are all extremized. }\end{array}$ \\
\hline $\begin{array}{l}\text { Further evaluation - some weaknesses and } \\
\text { omissions noted }\end{array}$ & $\begin{array}{l}\text { Unavoidably, there are reviews with debates and } \\
\text { controversies on the structure and some views of } \\
\text { this book. Indeed, scholars and researchers may } \\
\text { have respective opinions and views on the } \\
\text { definition of the term "terrorism", the } \\
\text { categorization of terrorism, or the staged division } \\
\text { of the history of terrorism. Hence, precisely } \\
\text { speaking, these are not the features that might be } \\
\text { called drawbacks or weaknesses. Still, it cannot } \\
\text { be denied that the parts of the description and } \\
\text { narration account for a great proportion in the } \\
\text { main body. }\end{array}$ \\
\hline \multirow[t]{2}{*}{$\begin{array}{l}\text { Restatement of overall impression and } \\
\text { recommendation }\end{array}$} & $\begin{array}{l}\text { To conclude, this comprehensive monograph } \\
\text { clearly divides the rise of terrorism into three } \\
\text { main parts and brings us an argument-based } \\
\text { analysis of how terrorism emerged, including a } \\
\text { profound summary on the rise of terrorism. } \\
\text { Chaliand and Blin provide research insights and } \\
\text { new ideas on terrorism that completed the greater } \\
\text { part of the book. It also needs to be said that there } \\
\text { are other recognized contributors of some } \\
\text { chapters, such as Olivier Hubac-Occhipinti, Yves } \\
\text { Ternon, Philippe Migaux, François Gére, and } \\
\text { Rohan Gunaratna. }\end{array}$ \\
\hline & $\begin{array}{r}\text { Written by Zihao Zhang } \\
\text { Proofread by Irina Ubozhenko } \\
16.01 .2019 \\
\end{array}$ \\
\hline
\end{tabular}




\section{RESEARCH RESULTS}

Hence, the above described practical example from teaching and learning experience of the authors has been claimed as productive in using the advantageous features of multimodality in developing academic skills based on the cognitive mind approach, conscious speculations, while analyzing modern topical research issues through their critical evaluation. The case study has proved the potential didactic resourcefulness of the following combination of cognitive elements used in class by the author with the purpose to develop the beginner researchers' critical thinking competence:

1) cognitive reading during the interactive lectures based on the teacher's presentation as visual aids, where key conceptual problem issues are marked through core word combinations and phrases;

2) mind-mapping ranking of relevant academic literature accompanied by a student's presentation, where they prove their choice of sources critically and show the conscious skill of distinguishing recognized literature from non-recognized one;

3) a collective panel discussion with the cognitive trigger issues prepared by the research project group in advance and accompanied by a collective presentation, were they all speak and participate in the question-answer session:

4) cognitive writing, where the teacher's verbal design prompts serve as elements of assistance in minding the proper structure of the given academic format of a book review.

Almost all regular modes (linguistic, visual, aural, spatial, textual) have been combined and served in class to create a single teaching algorithm of mastering fundamental research skills of critical perception and analysis.

\section{Practical Value}

The current study contributes to the development of the academic skills of critical thinking and multidimensional analysis, when teaching $\mathrm{PhD}$ and other postgraduate students and young researchers interested in political science, sociolinguistics, communication strategies and other related fields of the Humanities. The models suggested in our investigation will assist those striving to use their creative potential in analytical research activities and is primarily targeted at beginners in science, who search for broadening their professional outlook and strengthening their analytical critical evaluation research competences.

\section{DISCUSSION}

Accumulating all said before, as a debatable point, on having read our paper, we invite the reader to dwell prospectively on the multimodality thesaurus more profoundly. The issue of multimodal teaching and learning has been apparently referred to creative instruments triggering research analytics as it is. And if to admit the viewpoint of Prof. L. Chernyakhovskaya regarding the fact, that "people acquire cognitive information as a result of life experience, while language competence is both inherited and socially acquired knowledge", then cognitive reading analysis of professional discourse literature followed by its critical assessment in the format of a book review for the research journal might be proved as an effective tool of developing basic research analysis skills that are so important for young scholars, $\mathrm{PhD}$ and other post graduate students, in particular. (Chernyakhovskaya 2011) 


\section{CONCLUSION}

To conclude, in didactic terms, it proves to be of vital significance to teach beginner researchers, how to distinguish written ideas presentation from oral presentation of the same contents, taking into account different structure, format, vocabulary and style principles of written and oral academic discourse composition. Multimodality has been considered by the authors to be one of the most convenient and effective ways to make it possible to combine various techniques of messages presentation in academic discourse: both logical, laconic, compressing and visual, audio, graphic devices of cognitive operations training should be accumulated in the process of teaching.

\section{REFERENCES}

Chernyakhovskaya, Leonora. The Structure of Text Contents. Russian Journal of Communication, Vol.4, No. 3/4, 2011 http://www.russcomm.ru/rca_biblio/text/ RJCVol4Nos3-4.pdf

Code of Good Practice in Research. University of Glasgow. Version 2.6 (10 July 2018). Research and Innovation Services. https://www.gla.ac.uk/media/media_614208_en.pdf

Husarova, Zuzana. A Method of Teaching Multimodal Creative Writing. Studies in Foreign Language Education, No. 4, 2012 https://www.academia.edu/5606490/A_Method_ of_Teaching_Multimodal_Creative_Writing

Jianxin, Liu. Multimodal Educational Assessment: From Transmissive Learning to Creative Production. Journal of Educational Policies and Current Practices 2014; 1(1): 1-11 ISSN: 2147-3501 (Print) 2148-9688 (Online) DOI: 10.15340/2147350111797 https://www.researchgate.net/publication/280809542_Multimodal_Educational_Asses sment_From_Transmissive_Learning_to_Creative_Production

Marchetti, Lorena and Cullen, Peter. A Multimodal Approach in the Classroom for Creative Learning and Teaching. (2016). CASALC. Review 2/2016-2017, 2, pp. 39-51. https://pdfs.semanticscholar.org/c5ee/b0d8da329c0c777debfde3cc513b5f1ff868.pdf

Matsumura, L.C., Correnti, R. and Wang, E. Classroom Writing Tasks and Students' Analytic Text-Based Writing. Reading Research Quarterly, 50 (4). 417 - 438. ISSN 0034-0553. 2015

Paul, Richard and Elder, Linda. A Guide for Educators to Critical Thinking Competency Standards: Standards, Principles, Performance Indicators, and Outcomes, With a Critical Thinking Master Rubric. The Foundation for Critical Thinking Press. 2007. http://www.criticalthinking.org/files/SAM_Comp\%20Stand_07opt.pdf

Polziehn, Renee. Skills Expected from Graduate Students in Search of Employment in Academic and Non-Academic Settings. University of Alberta, Faculty of Graduate Studies and Research. (Revised January 2011) https://pdfs.semanticscholar.org/ cda8/ed2dc692727b43625d447a10d287dae6ca6f.pdf

Schultz, J.M. Mapping and Cognitive Development in the Teaching of Foreign Language Writing. The French Review. Vol. 64. No. 6 (May, 1991), pp. 978-988. https://www.jstor.org/stable/396091

The official instructions documentation for doctoral researchers of the University of Edinburgh. $\quad$ http://www.docs.hss.ed.ac.uk/iad/Postgraduate/PhD_researchers/PhD_ Skills_Guide.doc 